\title{
EFFECT OF LICORICE ROOT EXTRACT AND HUMIC ACID ON YIELD CHARACTERS OF SUMMER SQUASH (Cucurbita pepo L.)
}

\author{
Pshtwan J. M. Al-Zebari and Taha Z. SARHan \\ Dept. of Horticulture, Akree Technical College, Duhok Polytechnic University, Kurdistan Region-Iraq
}

(Received: July 11, 2019; Accepted for Publication: September 1, 2019)

\begin{abstract}
Field experiment was indicated at the experimental vegetable farms, college of agriculture, Duhok University, Kurdistan region-Iraq during the spring growing season of 2018, to evaluate the impact of licorice root extract $\left(0,5,10 \mathrm{~g} . \mathrm{L}^{-1}\right)$ and humic acid $\left(0,2,4 \mathrm{~g} . \mathrm{L}^{-1}\right)$ as foliar exercise on yield traits of summer squash (Cucurbita pepo L.) (cv.Naji F1). These experiments were laid out in a factorial arrangement in randomized complete block design (F-RCBD) with three replications. The results of this experiment showed that foliar spray of squash plants with licorice root extract at $10 \mathrm{~g} . \mathrm{L}^{-1}$ recorded highest value in most of yield traits and in terms the early yield $\left(0.389 \mathrm{~kg}^{-p l a n t}{ }^{-1}\right)$ was significantly increased. Moreover, spraying plants with humic acid at level $2 \mathrm{~g} . \mathrm{L}^{-1}$ the yield characters of squash plants was significantly increased in traits of early yield $\left(0.383 \mathrm{~kg}_{\text {.plant }}{ }^{-1}\right)$ and marketable yield $\left(34.86\right.$ ton.ha $\left.^{-1}\right)$, while humic acid spray at level $4 \mathrm{~g} . \mathrm{L}^{-1}$ significant affect on fruit number (13.81), fruit length $(14.14 \mathrm{~cm})$, fruit diameter $(3.65$ $\mathrm{cm})$, average fruit weight $(123.41 \mathrm{gm})$, total yield $\left(1.707 \mathrm{~kg}\right.$.plant $\left.{ }^{-1}\right)$ and total yield $\left(39.61\right.$ ton.ha $\left.^{-1}\right)$, except the unmarketable yield (4.656 ton.ha $^{-1}$ ) were decreased with increasing the level of humic acid. In addition, the combination treatments between licorice root extract at $10 \mathrm{~g} . \mathrm{L}^{-1}$ and humic acid at $4 \mathrm{~g} . \mathrm{L}^{-1}$ gave the highest value in the most of yield parameters in studied summer squash plants.
\end{abstract}

KEY WORDS: Foliar spray, Licorice Root Extract, Humic Acid, Yield, Summer Squash. https://doi.org/10.26682/ajuod.2019.22.2.5

\section{INTRODUCTION}

Summer squash considered the edible highly different species. This crop belongs to the family cucurbitaceae. Summer squash is a viewed the most popular vegetable crops in Iraq particularly during spring seasons. The cultivated area in Iraq is about (148) thousand hectares and the average rate of production was $(15,472$ t/ha. ) in 2012 (Annual Statistic Book, 2012), and this amount of yield is excessively low as contrasted with the world production.

One of the approaches to expand productivity is the utilization of modern technologies in agriculture, including modern nutrition and cultivars, which is one of the method of increasing growth and production (Esho and Saeed, 2016). Nowadays, numerous researcher is centered on possibility of utilizing natural plant extracts to increase productivity is the use of licorice extract (Glycyrrhiza glabrag) which is a family of Leguminoseae plants (Newall et al., 1996).

Recent studies demonstrated that plant extracts could be utilized as an elective that is safer than chemically synthesized growth regulators and fertilizers. Numerous researches (Al-Ajeeli.,2005) ( Moses et al.,2002)( Sabry et al.,2009) noticed that extract of licorice roots (Glycyrrhiza glabra) contain a few compounds, which have comparable impact to that of growth promoters, a wide range of minerals $(\mathrm{Ca}, \mathrm{K}, \mathrm{Mg}$, $\mathrm{Fe}, \mathrm{Zn}, \mathrm{P}$ ), amino acids (alanine, lysine, arginine), vitamins (B1, B2,B6), and furthermore carbohydrate and nitrogen. It likewise contains mevalonic acid utilized in gibberellins blended (AL-Marsoumi.,1999). Hussain,W.A. (2002) noticed that spraying the cucumber plants with licorice root extract at rates of $2.5 \mathrm{~g} . \mathrm{L}^{-1}$ resulted in a significant increased fruit weight and total yield. Al-Sahaaf et al., (2002) reported licorice extract had positive impact in increased the early yield and total yield of tomato plants.

Humic acid (HA) is a promising natural resource that can be utilized as an alternative to synthetic fertilizers to increase crop production 
(Nikbakht et al., 2008). Several researchers have pointed out that humic acid increase fruit yield, fruits number per plant, fruit length of squash (Sensoy et al .,2013; El-masry et al ., 2014) and of cucumber (Bozorgi et al., 2012; El -Nemr et al ., 2012; Sarhan and Yousi f, 2012). Hafez, (2004) mentioned that the application humic acid led to enhanced plant growth, increased plant productivity and enhanced squash plant quality.

Benyamin Esho, K. (2017) established the application of humic acid on summer squash plants increased fruit length, number of fruits.plant ${ }^{-1}$ and total yield.

Thus, the main objective of this study is to investigate the impact of foliar spray of licorice root extract and humic acid with various concentrations on yield characteristic of summer squash plants under climatic condition of duhok provinces, Kurdistan reign, Iraq.

\section{MATERIALS AND METHODS}

The experiment was carried out at the experimental vegetable Farm, College of Agriculture, University of Dohuk, Iraqi Kurdistan region, during spring season of 2018, to study the impact of foliar spray of licorice root extract $\left(0,5,10\right.$ g. $\left.\mathrm{L}^{-1}\right)$ and humic acid $(0,2$, 4 g. $\left.\mathrm{L}^{-1}\right)$ on yield traits of summer squash (Cucurbita pepo L.) (cv.Naji hybrid). Physical and chemical analysis of the experimental soil assessed according to (Page et al. 1982) is shown in Table

(1).

Table (1): Some physical and chemical properties of the studied soil in the field

\begin{tabular}{ccc}
\hline Characteristics & Measuring units & Amount \\
\hline & Volumetric distribution of soil separate & \\
\hline Sand & Percentage (\%) & 5.40 \\
\hline Silt & Percentage $(\%)$ & 29.0 \\
\hline Clay & Percentage $(\%)$ & 65.6 \\
\hline Soil texture & ---- & Clay \\
\hline & Available nutrient content & \\
\hline Total-N & $\mathrm{mg} / \mathrm{l}$ & 70.04 \\
\hline Available phosphorus & $\mathrm{mg} / \mathrm{l}$ & 74.0 \\
\hline Available potassium & $\mathrm{mg} / \mathrm{l}$ & 85 \\
\hline Available calcium & $\mathrm{mmol} \mathrm{C}^{-1}$ & 2.60 \\
\hline Organic matter(OM) & Percentage $(\%)$ & 1.89 \\
\hline Soil pH & $1: 1$ in peste & 7.69 \\
\hline Electrical Conductivity & dsm ${ }^{-1 / \mathrm{cm}}$ & 0.47 \\
\hline
\end{tabular}

* Where the soil analysis was carried out at soil and water science laboratory, College of Agriculture, Dohuk University.

\section{Preparation and application of licorice root extract}

Dried licorice root powder was sifted and weighed according to concentrations required for the study 5 and $10 \mathrm{~g} . \mathrm{L}^{-1}$. Then soaked in a liter of distilled water at $50^{\circ} \mathrm{C}$ for 24 hours and then filtered several times and supplement the final volume to liter. (Elrys \& Merwad, 2017). The elements analyses in Licorice roots extract are showed in table

(2).

Table (2): The elements of licorice root extract analyses

\begin{tabular}{lcccccccccc}
\hline Element & $\mathrm{Fe}^{+3}$ & $\mathrm{Cr}^{+3}$ & $\mathrm{Cu}^{+2}$ & $\mathbf{Z n}^{+2}$ & $\mathbf{C d}^{+2}$ & $\mathbf{P b}^{+2}$ & $\mathbf{N i}^{+2}$ & $\mathbf{S e}^{-2}$ & $\mathbf{B}^{+1}$ & $\mathbf{A l}^{+3}$ \\
\hline $\mathrm{ppm}$ & 741.0 & 15.0 & 465.0 & 145.0 & 24.0 & 26.0 & 1.0 & 0.0 & 343.0 & 0.0 \\
\hline
\end{tabular}

The squash plants were sprayed three times at 10 day intervals with various levels of humic acid at stage after the appearance of 3-4 true leaf on April $22^{\text {th }}$, with 10 days interval between them, beginning from 21 days after sowing.Moreover, licorice root extract sprayed also three times at stage flowering on April $26^{\text {th }}$, after 25 days from seed sowing. The summer 
squash foliage were completely wetted with licorice root extract and humic acid in order to accomplish faster and more effective absorption of both treatments during late afternoon (Hull et al.,1975).

The experiment involved nine treatments (3 levels of licorice root extract $\mathrm{x} 3$ levels of humic acid) were arranged according to a Factorial Randomized Complete Block Design (F-RCBD). Each treatment was replicated three times and each replicate was represented one terrace. Data on yield parameters were statistically analyzed using SAS program (SAS, 2001) and comparison among average was done by utilizing Duncan's Multiple Range test at 5\% level to verify the differences between means of treatments (Al-Rawi and Khalaf - Allah., 2000).

Information of data was collected by selected five plants randomly for each experimental unit. For yield characteristics data were collected on early yield $\left(\mathrm{kg} . p l a n t^{-1}\right)$, total yield $\left(\mathrm{kg} \cdot\right.$ plant $\left.^{-1}\right)$, total yield (ton.ha ${ }^{-1}$ ), marketable yield (ton.ha ${ }^{-1}$ ), unmarketable yield (ton.ha ${ }^{-1}$ ), fruit length $(\mathrm{cm})$, fruit diameter $(\mathrm{cm})$ and average fruit weight (gm).

\section{RESULTS AND DISCUSSION}

Table (3) below illustrated the impact of licorice root extract on fruits number remarked no significant effect among concentration of licorice root extract. While, regarding to the effect of humic acid on fruits number.plant ${ }^{-1}$ had significant increase, the higher fruits number was resulted when spray squash plant with 4 g.L${ }^{1}$ humic acid (13.81fruits.plant ${ }^{-1}$ ) as contrasted to control treatments (11.97 fruits.plant $\left.{ }^{-1}\right)$.The combination between humic acid and licorice extract remarked significant influence on fruits number at rate of humic acid $4 \mathrm{~g} . \mathrm{L}^{-1}$ and licorice at rate $10 \mathrm{~g} . \mathrm{L}^{-1}$ (14.80) fruit compared with control (11.23) fruit by increasing $31.78 \%$. This improvement in fruit quality may because of the humic acid activated the biochemical processes in plants (respiration, photosynthesis and chlorophyll content) leading to improved quality

(Abolina and Tashkhadzhaev 1968).

Table (3): Effect of licorice root extract, humic acid and their interaction on fruits number.plant ${ }^{-1}$ of summer squash plants.

\begin{tabular}{|c|c|c|c|c|c|}
\hline \multirow[t]{2}{*}{ Cultivar } & \multirow{2}{*}{$\begin{array}{l}\text { Humic Acid } \\
\left(\mathrm{g} \cdot \mathrm{L}^{-1}\right)\end{array}$} & \multicolumn{3}{|c|}{ Licorice Extract $\left(\mathrm{g} \cdot \mathrm{L}^{-1}\right)$} & \multirow[t]{2}{*}{ Humic Effect } \\
\hline & & 0 & 5 & 10 & \\
\hline \multirow{3}{*}{$\begin{array}{c}\text { Humic } \\
\times \\
\text { Licorice }\end{array}$} & 0 & $11.23 \mathrm{~d}$ & $12.36 \mathrm{~cd}$ & $12.33 \mathrm{~cd}$ & $11.97 b$ \\
\hline & 2 & $13.76 \mathrm{a}-\mathrm{c}$ & $13.82 \mathrm{ab}$ & $13.04 \mathrm{bc}$ & $13.54 \mathrm{ab}$ \\
\hline & 4 & $12.93 \mathrm{bc}$ & $13.69 \mathrm{a}-\mathrm{c}$ & $14.80 \mathrm{a}$ & $13.81 \mathrm{a}$ \\
\hline Lic & & $12.64 \mathrm{a}$ & $13.29 \mathrm{a}$ & $13.39 \mathrm{a}$ & \\
\hline
\end{tabular}

The column, row and their interactions with the same letters are not significantly different from each other according to Duncan's multiple range test at level $(\alpha=0.05)$.

Table (4) showed that treated summer squash with foliar spray of licorice root extract at level 5 g.L. $\mathrm{L}^{-1}$ increased the average of fruit weight (g.plant ${ }^{-1}$ ), while humic acid spray significantly affected on the average of fruit weight (g.plant ${ }^{-1}$ ) the maximum value (123.41 g.plant $^{-1}$ ) observed at rate $4 \mathrm{~g} . \mathrm{L}^{-1}$ of humic acid and the minimum value observed with control treatments ( 97.63 g.plant $\left.{ }^{-1}\right)$. This result was in agreement with the
El-Aal et al.(2010) where the foliar apply of humic acid on squash plant led to an increase in plant growth and gets high yield productivity. The impact of the interaction between humic acid and licorice root extract on the average fruit weight were observed significant difference, humic acid at rate $4 \mathrm{~g} . \mathrm{L}^{-1} \times 10 \mathrm{~g} . \mathrm{L}^{-1}$ of licorice gave the highest value $\left(126.55\right.$ g.plant $\left.^{-1}\right)$ on fruit weight as compared lowest value (93.53g.plant ${ }^{-}$ 
$\left.{ }^{1}\right)$ at control both application by increasing $35.30 \%$.

The role of licorice root extract as foliar spray may be due to that licorice roots extraction mainly containing glycyrrhizin, flavonoids, reducing and non-reducing sugars, plant gums, resins, essential oils, inorganic salts and low levels of nitrogenous compounds like proteins, individual amino acids and nucleic acids (Isbruker and Burdock, 2006).

Table (4): Effect of licorice root extract, humic acid and its interaction on the average fruit weight $(\mathrm{gm})$.plant ${ }^{-1}$ of summer squash plants.

\begin{tabular}{|c|c|c|c|c|c|}
\hline \multirow[t]{2}{*}{ Cultivar } & \multirow{2}{*}{$\begin{array}{l}\text { Humic Acid } \\
\left(g \cdot L^{-1}\right)\end{array}$} & \multicolumn{3}{|c|}{ Licorice Extract $\left(\mathrm{g} \cdot \mathrm{L}^{-1}\right)$} & \multirow[t]{2}{*}{ Humic Effect } \\
\hline & & 0 & 5 & 10 & \\
\hline \multirow{3}{*}{$\begin{array}{c}\text { Humic } \\
\times \\
\text { Licorice }\end{array}$} & 0 & $93.53 \mathrm{c}$ & $100.58 \mathrm{c}$ & $98.78 \mathrm{c}$ & $97.63 \mathrm{~b}$ \\
\hline & 2 & $121.90 \mathrm{ab}$ & $118.56 \mathrm{ab}$ & $114.56 \mathrm{~b}$ & $118.34 \mathrm{a}$ \\
\hline & 4 & $121.08 \mathrm{ab}$ & $122.58 \mathrm{ab}$ & $126.55 \mathrm{a}$ & $123.41 \mathrm{a}$ \\
\hline Lic & ct & $112.17 \mathrm{a}$ & $113.91 \mathrm{a}$ & $113.30 \mathrm{a}$ & \\
\hline
\end{tabular}

The column, row and their interactions with the same letters are not significantly different from each other according to Duncan's multiple range test at level $(\alpha=0.05)$.

Data presented in Table (5) showed that foliar spray of licorice root extract significantly increased on the early yield, the heights yield observed in 10 g.L $\mathrm{L}^{-1}$ of licorice $\left(0.389 \mathrm{~kg}\right.$.plant $\left.{ }^{-1}\right)$ as compared with the other treatments. While treated plants was foliar sprayed with humic acid at rate $2 \mathrm{~g} . \mathrm{L}^{-1}$ significant increased the early yield (kg.plant ${ }^{-1}$ ) of summer squash plants. In the same table the effect of the interaction between foliar apply with licorice root extract and humic acid significantly increased early yield $\left(\mathrm{kg}\right.$. plant $\left.^{-1}\right)$ the highest value $\left(0.500 \mathrm{~kg} \cdot\right.$ plant $\left.^{-1}\right)$ recorded when plant treats 10 g.L. $\mathrm{L}^{-1}$ of licorice $\mathrm{x}$ 4 g. $\mathrm{L}^{-1}$ humic acid as contrasted with the lowest value (0.249 kg.plant $\left.{ }^{-1}\right)$ observed at control treatments, which increased by $50.2 \%$.

This increase may be attributed to the fact that the licorice root extract contains more than 100 various compounds, some of which accumulated in large quantities, the most important compounds are phenolic compounds, mevalonic acid, triterpene sapoins, protein amino acid (asparagin), lignins, vitamins like (B1, B2, B3, B6, E and C), biotin, folic acid, pantothenic acid and polysaccharide (glucose, fructose, sucrose and maltose) all of which play an important role in improving plant growth and thus increasing the production of yield (Rossi, 1999 and Arystanova et al., 2001).

Table (5): Effect of licorice root extract, humic acid and their interaction on the early yield (kg.plant $\left.{ }^{1}\right)$ of summer squash plants.

\begin{tabular}{|c|c|c|c|c|c|}
\hline \multirow[t]{2}{*}{ Cultivar } & \multirow{2}{*}{$\begin{array}{l}\text { Humic Acid } \\
\left(\mathrm{g} \cdot \mathrm{L}^{-1}\right)\end{array}$} & \multicolumn{3}{|c|}{ Licorice Extract $\left(\mathrm{g} \cdot \mathrm{L}^{-1}\right)$} & \multirow[t]{2}{*}{ Humic Effect } \\
\hline & & 0 & 5 & 10 & \\
\hline \multirow{3}{*}{$\begin{array}{c}\text { Humic } \\
\times \\
\text { Licorice }\end{array}$} & 0 & $0.249 \mathrm{~d}$ & $0.281 \mathrm{~cd}$ & $0.330 \mathrm{~cd}$ & $0.287 b$ \\
\hline & 2 & $0.449 a b$ & $0.361 \mathrm{bc}$ & $0.338 \mathrm{~cd}$ & $0.383 \mathrm{a}$ \\
\hline & 4 & $0.250 \mathrm{~d}$ & $0.356 \mathrm{bc}$ & $0.500 \mathrm{a}$ & $0.369 \mathrm{a}$ \\
\hline
\end{tabular}

The column, row and their interactions with the same letters are not significantly different from each other according to Duncan's multiple range test at level $(\alpha=0.05)$. 
Table (6) noticed there is no significant increase between licorice root extract and humic acid on the total yield kg.plant ${ }^{-1}$. According to the effect of interaction between humic acid and licorice extract on the total yield, observed significant increases in yield production and the highest value recorded between $2 \mathrm{~g} . \mathrm{L}^{-1}$ humic acid $\times 10 \mathrm{~g} . \mathrm{L}^{-1}$ of licorice root extract $\left(1.805 \mathrm{~kg}\right.$. plant $^{-}$

1 ) compared with the lowest value (1.354 kg.plant ${ }^{-1}$ ) of untreated plants with increasing $33.30 \%$. These results may be due to the strongest plant growth that led to hormone-like activities of the humic acid through their involvement in increasing, photosynthesis, protein synthesis, antioxidant and different enzymatic reactions. (Muscolo et al.,1993; Zhang and Schmidt, 2000).

Table (6): Effect of licorice root extract, humic acid and their interaction on the total yield (kg.plant $\left.{ }^{-1}\right)$ of summer squash plants.

\begin{tabular}{|c|c|c|c|c|c|}
\hline \multirow[t]{2}{*}{ Cultivar } & \multirow{2}{*}{$\begin{array}{l}\text { Humic Acid } \\
\left(\mathrm{g} \cdot \mathrm{L}^{-1}\right)\end{array}$} & \multicolumn{3}{|c|}{ Licorice Extract $\left(\mathrm{g} \cdot \mathrm{L}^{-1}\right)$} & \multirow[t]{2}{*}{ Humic Effect } \\
\hline & & 0 & 5 & 10 & \\
\hline \multirow{3}{*}{$\begin{array}{c}\text { Humic } \\
\times \\
\text { Licorice }\end{array}$} & 0 & $1.354 \mathrm{~b}$ & $1.603 \mathrm{ab}$ & $1.537 \mathrm{ab}$ & $1.498 \mathrm{a}$ \\
\hline & 2 & $1.537 \mathrm{ab}$ & $1.672 \mathrm{a}$ & $1.805 \mathrm{a}$ & $1.671 \mathrm{a}$ \\
\hline & 4 & $1.787 \mathrm{a}$ & $1.733 \mathrm{a}$ & $1.600 \mathrm{ab}$ & $1.707 \mathrm{a}$ \\
\hline & ect & $1.560 \mathrm{a}$ & $1.669 \mathrm{a}$ & $1.647 \mathrm{a}$ & \\
\hline
\end{tabular}

The column, row and their interactions with the same letters are not significantly different from each other according to Duncan's multiple range test at level $(\alpha=0.05)$.

Licorice root extract spray at rate $10 \mathrm{~g} . \mathrm{L}^{-1}$ on plants increased the total yield ton.ha ${ }^{-1}$ (Table 7 ), while humic acid apply at level 4g. $\mathrm{L}^{-1}$ significantly affected on the total yield ton.ha ${ }^{-1}$ measured (39.61 ton.ha ${ }^{-1}$ ). The interaction between humic acid and licorice extract, data shows that humic acid $2 \mathrm{~g} . \mathrm{L}^{-1}$ with $10 \mathrm{~g} . \mathrm{L}^{-1}$ of licorice gave the highest value (42.71 ton.ha ${ }^{-1}$ ) as compared with the lowest value (29.65 ton.ha ${ }^{-}$ 1 ) at control interaction, which increased by $44.04 \%$.Increasing the quantitative yield character of summer squash plant could be explained as humic acid is rich in organic and mineral compound which are essential factor to plant growth and increasing the quality and quantity of the crop (Gad El-Hak, et al., 2012).These increments of quantitative yield obtained by (Karakurt et al., 2009; Brownell et al., 1987; Yildirim, 2007) reported that the foliar spray of humic acid promotes plant growth and increase yield and quantity in a number of plant species at least partially by increasing uptake of nutrients.

Table (7): Effect of licorice root extract, humic acid and their interaction on the total yield (ton.ha ${ }^{-1}$ )

\begin{tabular}{|c|c|c|c|c|c|}
\hline \multirow[t]{2}{*}{ Cultivar } & \multirow{2}{*}{$\begin{array}{l}\text { Humic Acid } \\
\left(\mathrm{g} \cdot \mathrm{L}^{-1}\right)\end{array}$} & \multicolumn{3}{|c|}{ Licorice Extract $\left(\mathrm{g} \cdot \mathrm{L}^{-1}\right)$} & \multirow[t]{2}{*}{ Humic Effect } \\
\hline & & 0 & 5 & 10 & \\
\hline \multirow{3}{*}{$\begin{array}{c}\text { Humic } \\
\times \\
\text { Licorice }\end{array}$} & 0 & $29.65 \mathrm{e}$ & $31.68 \mathrm{De}$ & $32.30 \mathrm{c}-\mathrm{e}$ & $31.21 \mathrm{~b}$ \\
\hline & 2 & $36.79 b-d$ & $37.83 \mathrm{a}-\mathrm{c}$ & $42.71 \mathrm{a}$ & $39.11 \mathrm{a}$ \\
\hline & 4 & $41.74 a b$ & $40.05 a b$ & $37.03 \mathrm{a}-\mathrm{d}$ & $39.61 \mathrm{a}$ \\
\hline $\mathbf{L i}$ & ffect & $36.07 \mathrm{a}$ & $36.52 \mathrm{a}$ & $37.35 \mathrm{a}$ & \\
\hline
\end{tabular}

The column, row and their interactions with the same letters are not significantly different from each other according to Duncan's multiple range test at level $(\alpha=0.05)$. 
The results presented in Table (8) show there is no significant effect on the marketable yield ton.ha ${ }^{-1}$ when plant treated with licorice root extract treatments. According to the effect of humic acid resulted in significant increase in the marketable yield at level $2 \mathrm{~g} . \mathrm{L}^{-1}$ as compared with other treatments. Relating to the interaction between humic acid and licorice extract observed significant increase when plants treated by $4 \mathrm{~g} . \mathrm{L}^{-1}$ humic acid and $10 \mathrm{~g} . \mathrm{L}^{-1}$ licorice extract with highest value (36.50 ton.ha ${ }^{-1}$ ) as compared with control both of foliar application (23.42 ton.ha $\left.{ }^{-1}\right)$. This result might be due to the comparability of licorice root extract in behavior with gibberellins that improve flowering rates. These ingredients contain mevalonic acid which enhance vegetative growth as a result of the stimulation of enzymes that are important for the change of complex compounds into simple compounds, and energy efficient tretment required for plant growth traits and yield traits (Sahi, 2006; AL-Jebouri et al., 2010; Luyckx et al., 2017 and Cuong et al., 2017).improvement of the quality of marketable yield may be due to the humic acid high content of potassium.

Table (8): Effect of licorice root extract, humic acid and their interaction on the marketable yield (ton.ha ${ }^{-1}$ ) of summer squash plants.

\begin{tabular}{|c|c|c|c|c|c|}
\hline \multirow[t]{2}{*}{ Cultivar } & \multirow{2}{*}{$\begin{array}{c}\text { Humic Acid } \\
\left(\mathrm{g} \cdot \mathrm{L}^{-1}\right)\end{array}$} & \multicolumn{3}{|c|}{ Licorice Extract $\left(\mathrm{g} \cdot \mathrm{L}^{-1}\right)$} & \multirow[t]{2}{*}{ Humic Effect } \\
\hline & & $\overline{0}$ & 5 & 10 & \\
\hline \multirow{3}{*}{$\begin{array}{c}\text { Humic } \\
\times \\
\text { Licorice }\end{array}$} & 0 & $23.42 \mathrm{c}$ & $26.82 \mathrm{c}$ & $27.74 \mathrm{bc}$ & $25.99 \mathrm{~b}$ \\
\hline & 2 & $36.48 \mathrm{a}$ & $35.38 \mathrm{a}$ & $32.72 \mathrm{a}$ & $34.86 \mathrm{a}$ \\
\hline & 4 & $31.61 \mathrm{ab}$ & $32.95 \mathrm{a}$ & $36.50 \mathrm{a}$ & $33.69 \mathrm{a}$ \\
\hline Lico & ct & $30.50 \mathrm{a}$ & $31.72 \mathrm{a}$ & $32.32 \mathrm{a}$ & \\
\hline
\end{tabular}

The column, row and their interactions with the same letters are not significantly different from each other according to Duncan's multiple range test at level $(\alpha=0.05)$.

Table (9) resulted that there is a decrease in the unmarketable yield (ton.ha ${ }^{-1}$ ) when plants treated with foliar spray of licorice root extract at rate $5 \mathrm{~g} . \mathrm{L}^{-1}$, while according to the effect of humic acid, untreated treatments recorded the highest unmarketable yield (6.624 ton.ha $\left.{ }^{-1}\right)$ compared with the other treatments, this means that there is a significant affect when plants sprayed by humic acid at both levels $\left(2\right.$ g.L $\mathrm{L}^{-1}, 4$ g. $\mathrm{L}^{-1}$ ) which lead to decrease unmarketable yield. Concerning the effect of both foliar applications (humic acid + licorice extract) on unmarketable yield showed significant differences, the highest unmarketable fruits yield observed with both control of application measured (7.614 ton.ha $\left.{ }^{-1}\right)$ with lowest production on the unmarketable yield at level $4 \mathrm{~g} . \mathrm{L}^{-1}$ of humic acid and no spray of licorice (3.586 ton.ha-1 ${ }^{-1}$. Salman et al., (2005) examined that the humic acid applied on watermelon plants promotes to an increase in the overall yield of all hybrids. The increase in yield in summer squash plant may due to the increase in the number of distillate blooms which led to an increase in the number of fruits that affect the yield and total crop. plants $^{-1}$. 
Table (9): Effect of licorice root extract, humic acid and their interaction on the unmarketable yield (ton.ha ${ }^{-1}$ ) of summer squash plants.

\begin{tabular}{|c|c|c|c|c|c|}
\hline \multirow[t]{2}{*}{ Cultivar } & \multirow{2}{*}{$\begin{array}{l}\text { Humic Acid } \\
\left(g \cdot L^{-1}\right)\end{array}$} & \multicolumn{3}{|c|}{ Licorice Extract $\left(\mathrm{g} \cdot \mathrm{L}^{-1}\right)$} & \multirow[t]{2}{*}{ Humic Effect } \\
\hline & & 0 & 5 & 10 & \\
\hline \multirow{3}{*}{$\begin{array}{c}\text { Humic } \\
\times \\
\text { Licorice }\end{array}$} & 0 & $7.614 \mathrm{a}$ & $5.570 \mathrm{ab}$ & $6.687 \mathrm{ab}$ & $6.624 \mathrm{a}$ \\
\hline & 2 & $5.666 a b$ & $5.019 a b$ & $4.640 a b$ & $5.108 \mathrm{~b}$ \\
\hline & 4 & $3.586 \mathrm{~b}$ & $4.289 a b$ & $6.093 \mathrm{ab}$ & $4.656 \mathrm{~b}$ \\
\hline & & $5.622 \mathrm{a}$ & $4.959 \mathrm{a}$ & $5.807 \mathrm{a}$ & \\
\hline
\end{tabular}

The column, row and their interactions with the same letters are not significantly different from each other according to Duncan's multiple range test at level $(\alpha=0.05)$.

Concerning the effect of spraying with licorice root extract, it increased the fruit length $(\mathrm{cm})$ at concentration $10 \mathrm{~g} . \mathrm{L}^{-1}$ resulting in $(12.69$ $\mathrm{cm}$ ), for the effect of foliar apply of humic acid showed a significant increase in fruit length at level $4 \mathrm{~g} . \mathrm{L}^{-1}$ measured $(14.14 \mathrm{~cm})$ contrasted with other treatments (Table 10).

The binary interaction between humic acid and licorice root extract on the fruit length, led to a significant increase that was noticed when plants treated at $4 \mathrm{~g} . \mathrm{L}^{-1}$ of humic acid $\times 10 \mathrm{~g} . \mathrm{L}^{-1}$ of licorice $(14.23 \mathrm{~cm})$ as compared to the untreated both of application $(10.67 \mathrm{~cm})$, caused an rising of $33.36 \%$. This increase in fruit length might be due to the activity of hormone like humic acid through their participation in cell respiration, photosynthesis and different enzymatic reaction and increase yield of squash crop (Heli et al., 2005).

Table (10): Effect of licorice root extract, humic acid and their interaction on the fruit length (cm). plant ${ }^{-1}$ of summer squash plants.

\begin{tabular}{|c|c|c|c|c|c|}
\hline \multirow[t]{2}{*}{ Cultivar } & \multirow{2}{*}{$\begin{array}{c}\text { Humic Acid } \\
\left(\mathrm{g} \cdot \mathrm{L}^{-1}\right)\end{array}$} & \multicolumn{3}{|c|}{ Licorice Extract $\left(\mathrm{g} \cdot \mathrm{L}^{-1}\right)$} & \multirow[t]{2}{*}{ Humic Effect } \\
\hline & & 0 & 5 & 10 & \\
\hline \multirow{3}{*}{$\begin{array}{c}\text { Humic } \\
\times \\
\text { Licorice }\end{array}$} & 0 & $10.67 \mathrm{c}$ & $10.80 \mathrm{c}$ & $10.93 \mathrm{c}$ & $10.80 \mathrm{c}$ \\
\hline & 2 & $13.15 \mathrm{~b}$ & $13.03 \mathrm{~b}$ & $12.91 \mathrm{~b}$ & $13.03 \mathrm{~b}$ \\
\hline & 4 & $14.05 \mathrm{a}$ & $14.15 \mathrm{a}$ & $14.23 \mathrm{a}$ & $14.14 \mathrm{a}$ \\
\hline & ect & $12.62 \mathrm{a}$ & $12.66 \mathrm{a}$ & $12.69 \mathrm{a}$ & \\
\hline
\end{tabular}

The column, row and their interactions with the same letters are not significantly different from each other according to Duncan's multiple range test at level $(\alpha=0.05)$.

Data listed in Table (11) indicated that there is no significant effect with foliar spray of licorice root extract as individual impact on fruit diameter, while humic acid spray as individual effect significantly affected on fruit diameter at rate $4 \mathrm{~g} . \mathrm{L}^{-1}$ which remarked $(3.65 \mathrm{~cm})$. Concerning the effect of interaction between humic acid and licorice extract significantly affected at a level of $4 \mathrm{~g} . \mathrm{L}^{-1}$ humic acid $\times 5 \mathrm{~g} . \mathrm{L}^{-1}$ of licorice $(3.68 \mathrm{~cm})$ on fruit diameter compared with smallest value $(2.78 \mathrm{~cm})$ observed from control treatments, by rising $32.37 \%$. This might be due to the fact that humic acid is rich in organic and mineral substances that are essential for plant growth and thus increase the quality and quantity of yield (Gad et al., 2012). Karakurt et al., (2009) concluded that the application spray for these substances also worked to improve growth, yield and quality in at least some plant species by increasing nutrient absorption. 
Table (11): Effect of licorice root extract, humic acid and their interaction on the fruit diameter $(\mathrm{cm})$. plant $^{-1}$ of summer squash plants.

\begin{tabular}{|c|c|c|c|c|c|}
\hline \multirow[t]{2}{*}{ Cultivar } & \multirow{2}{*}{$\begin{array}{l}\text { Humic Acid } \\
\left(\mathrm{g} \cdot \mathrm{L}^{-1}\right)\end{array}$} & \multicolumn{3}{|c|}{ Licorice Extract $\left(\mathrm{g} \cdot \mathrm{L}^{-1}\right)$} & \multirow[t]{2}{*}{ Humic Effect } \\
\hline & & 0 & 5 & 10 & \\
\hline \multirow{3}{*}{$\begin{array}{c}\text { Humic } \\
\times \\
\text { Licorice }\end{array}$} & 0 & $2.78 \mathrm{c}$ & $2.81 \mathrm{c}$ & $2.82 \mathrm{c}$ & $2.80 \mathrm{c}$ \\
\hline & 2 & $3.39 \mathrm{~b}$ & $3.37 \mathrm{~b}$ & $3.38 \mathrm{~b}$ & $3.38 \mathrm{~b}$ \\
\hline & 4 & $3.60 \mathrm{a}$ & $3.68 \mathrm{a}$ & $3.65 \mathrm{a}$ & $3.65 \mathrm{a}$ \\
\hline \multicolumn{2}{|c|}{ Licorice effect } & $3.26 \mathrm{a}$ & $3.29 \mathrm{a}$ & $3.28 \mathrm{a}$ & \\
\hline
\end{tabular}

The column, row and their interactions with the same letters are not significantly different from each other according to Duncan's multiple range test at level $(\alpha=0.05)$.

\section{CONCLUSION}

In this study, it can be concluded that from mentioned the above results the use of licorice root extract and humic acid as individual or combination via foliar spray gave the best results on the yield traits of summer squash plants.

\section{REFERENCES}

Abolina,B.I. and Tashkhadzhaev, A.T. (1968). Effects of Coal-Humic Fertilizers on the Activity of Physiological Processes in Plants and in the Yield of Potatoes in Uzbekistan. Guminovye Udabr.

Al-Ajeeli T. A. Z., (2005). Effect GA3 and some nutrients to produce Glycyrrhizgin and some other components in the plant Licorice (Glycyrrhiza glabra L.), Ph.D. dissertation, Faculty of Agriculture,University of Baghdad, Iraq.

Al-Jebouri, K.A.A., F.H., Hasoon, W.H.(2010). Role of spraying with some plant extracts in flowering of cucumber in plastic house. Iraqi. J. Agric. Sci., 41(1), 111-120

AL-Marsoumi H. G. K.,(1999). Effect of some factors in recipes vegetative growth and flowering and holds seed in three varieties of onion (Allium cepa L.), Ph.D. dissertation, Faculty of Agriculture, University of Baghdad, Iraq.

AL-Rawi , K. M. Khalaf-Allah (2000). Design and analysis of agricultural experiments.
Directorate of Book House for publishing and pressing. Mosul Univ. Iraq (In Arabic) .

Al-Sahaaf,F.H., Al-Juboory, M.K. and Al Dulaimy, R.M.H.(2002). Effect of licorice extract spraying on cracks types of pomegranate fruits. Ieaqi.J.Agric.Sci., $33(4), 85-90$

Annual Statistic Book (2012). Vegetable and field crop production. Directorate of Agriculture Statistical-Planning UnitMinistry Council-Iraqi Republic. (In Arabic).

Arystanova, T.; Irismetov, M. and Sophekova, A. (2001). Chromatographic determination of Glycyrrhizinic acid in Glycyrrhiza glabra preparation. Chem. Nat. Com., 37: 89-91.

Benyamin Esho, K., \& Saeed, S. H.(2017). Effect of humic acid on growth and yield of three cultivars of summer squash (Cucurbita pepo L.). Egypt. J. Exp. Biol. (Bot.), 13(2): 167 - 171.

Bozorgi, H. R., Bidarigh, S., Azarpour, E., Khosravi, R., \& Moraditochaee, M. (2012). Effects of natural zeolite application under foliar spraying with humic acid on yield and yield components of cucumber (Cucumis sativus L.). International Journal of Agriculture and Crop Sciences, 4(20), 1485-1488. 
Brownell, J. R., Nordstrom, G., Marihart, J., \& Jorgensen, G. (1987). Crop responses from two new leonardite extracts. Science of the total environment, 62, 491-499.

Cuong, T.X., Ullah, H., Datta, A. and Hanh, T.C. (2017). Effects of silicon-bBased fertilizer on growth, yield and nutrient uptake of rice in tropical zone of Vietnam. Rice Science, 24(5), 283 - 290. https://doi.org/10.1016/j.rsci.2017.06.002

El-Aal, F. S. A., Shaheen, A. M., Ahmed, A. A., \& Mahmoud, A. R. (2010). Effect of foliar application of urea and amino acids mixtures as antioxidants on growth, yield and characteristics of squash. Research Journal of Agriculture and Biological Sciences, 6(5), 583-588.

El-Masry, T. A., Osman, A. S., Tolba, M. S., \& El-Mohsen, Y. H. A. (2014). Increasing nitrogen efficiency by humic acid soil application to squash plants (Cucurbita pepo L.) grown in newly reclaimed saline soil. Egypt. J. Horticult, 41, 17-38.

El-Nemr, M. A., El-Desuki, M., El-Bassiony, A. M., \& Fawzy, Z. F. (2012). Response of growth and yield of cucumber plants (Cucumis sativus L.) to different foliar applications of humic acid and biostimulators. Australian Journal of Basic and Applied Sciences, 6(3), 630-637.

Elrys, A. S., \& Merwad, A. R. (2017). Effect of alternative spraying with silicate and licorice root extract on yield and nutrients uptake by pea plants. Egyptian Journal of Agronomy, 39(3), 279-292.

Esho, K. B., \& Saeed, S. H. (2016). Correlation and Genetic Parameters in Summer Squash (Cucurbita Pepo L.). Journal of Dynamics in Agricultural Research Vol, 3(3), 41-45.

Gad El-Hak, S.H.; A.M. Ahmed, and Y.M.M. Moustafa, (2012). Effect of foliar application with two antioxidants and humic acid on growth, yield and yield
Components of Peas (Pisum sativum L.). Journal of Horticultural Science and Ornamental Plants, 4 (3): 318-328.

Hafez, M. M. (2004). Effect of some sources of nitrogen fertilizer and concentration of humic acid on the productivity of squash plant. Egypt. J. Appli. Sci, 19, 293-309.

Heli, C.A. (2005). Influence of humic, fluvic, hydrophilic acid on the growth, photosynthetic and respiration of the dinoflagellate prorocentrum. Harmful Algae, 4: 603-618.

Hull HM, Morton HL, Wharrie JR (1975). Environmental influence on cuticle development and resultant foliar penetration. BotanicalReviews, 41: 421451.

Hussein, W.A. (2002). Effect of garlic and licorice extracts and urea on vegetative and flowering growth, yield and qualitative characters of cucumber. M.Sc. Thesis. College of agriculture. University of Baghdad. Iraq.

Isbruker, R.A. and G.A. Burdock (2006). Risk and safety assessment on the consumption of licorice roots, its extract and powder as a food ingredient, with emphasis on the pharmacology and toxicity of glycyrrhizin", Regul. Toxicol. Pharmacol., 46 : 167-192.

Karakurt, Y.; H. Unlu, and H. Padem, (2009). The influence of foliar and soil fertilization of humic acid on yield and quality of pepper. Acta Agric. Scand., 59: 233-237.

Luyckx, M., Hausman, J., Lutts, S. and Guerriero, G. (2017). Silicon and plants: Current knowledge and

Moses; T. N.; A. wheeb,W. ; AL-Hadithy,Z. andEllewy, A. N. (2002). Studying some components of the local licorice root powder Glyrrhizaglabra- L Journal of Agricultural Sciences Iraqi 38-30 -: (4) 34. 
Muscolo,A.; M. Felicim; G. Concheri and S. Nardi (1993). Effect of earthworm humic substances on esterase and peroxidase activity during growth of leaf explants of Nicotiana plumbaginifolia. Biology and Fertility of Soils, 15: 127-131.

Newall, C. A., Anderson, L. A., \& Phillipson, J. D. (1996). Herbal medicines. A guide for health-care professionals. The pharmaceutical press.

Nikbakht, A., Goli, S. A. H., Kargar, M., \& Ahmadzadeh, S. (2011). Effect of humic acid on yield and oil characteristics of Silybum marianum and Cucurbita pepo convar. pepo var. styriaca seeds. Herba Polonica, 57(4).

Page, A. L.; R. H. Miller and D. R. Keeney. (1982). Methods of analysis. Part two, chemical and microbiological properties (Second Edition). Amer Soc of Agronomy, Inc. Madison (U.S.A.).

Rossi, I. (1999). Medicinal Plants of the World. Vol. 2: Chemical constituents traditional and modern medicinal uses. Human Press, USA.

Sabry, G. H., Rizk-Alla, M. S., \& Abd ElWahab, M.A. (2009). Influence of effective micro-organisms, seaweed extract and amino acids application on growth, yield and bunch quality of Red globe grapevines. J. Agric. Sci. Mansoura Univ, 34(6), 5901-5921.

Sahi B. Gh.,(2006). Effect of liqurice root extract and calcium chloride spray on growth and flowering of (Antirrhinum majus L.), The Iraqi Journal of Agricultural Sciences, 37(3): 39-44.

Salman, S. R., Abou-Hussein, S. D., AbdelMawgoud, A. M. R., \& El-Nemr, M. A. (2005). Fruit yield and quality of watermelon as affected by hybrids and humic acid application. Journal of Applied Sciences Research, 1(1), 51-58.

SarhanTZ, Yousif KH.(2012). Effect of humic acid and biofertil izer (EM-1) on flowering and yield of cucumber (Cucumis sativus L.). The 1st Sci.Agric. Conf. 10-12th April 2012. J. Univ. Duhok 15(1): 22-33.

SAS (2001). SAS/STAT 'User's Guide for Personal Computer. Release 6.12.SAS Institute Inc, Cary, NC.,USA.

Sensoy, S., Ocak, E., Demir, S., \& Tufenkci, S.(2013). Effects of humic acid, whey and arbuscular mycorrhizal fungi (AMF) applications on seedling growth and Fusarium wilt in zucchini (Cucurbita pepo L.). Journal of Animal and Plant Sciences, 23, 507-513.

Yildirim E (2007). Foliar and soil fertilization of humic acid affect productivity and quality of tomato. Acta Agriculturae Scandinavica Section B-Soil Plant Science, 57: 182-186.

Zhang, X. and R.E. Schmidt, (2000). Hormone- containing products impact on antioxidant status of tall fescue and creeping bent grass subject to drought. Crop Sci. 40: 1344-1349. 


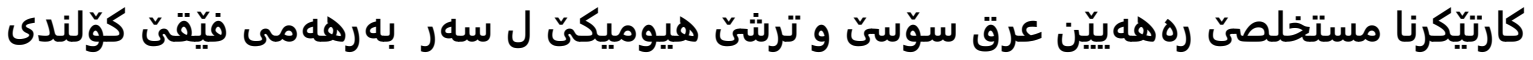
(Cucurbita pepo L.)

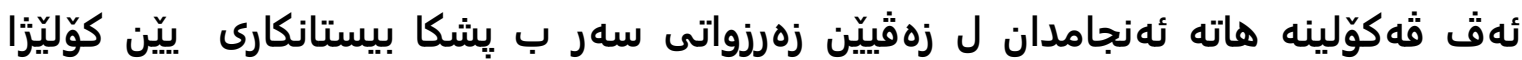

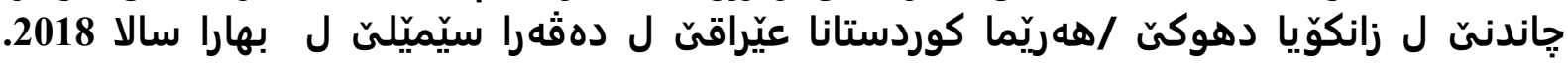

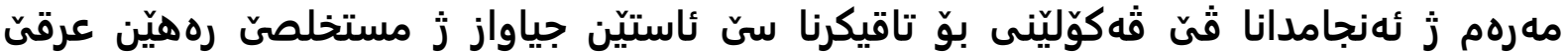

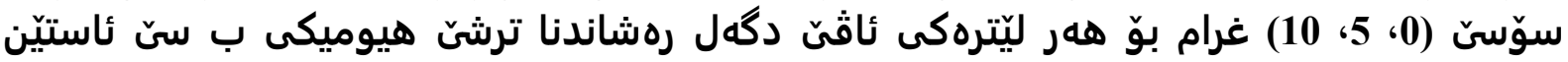

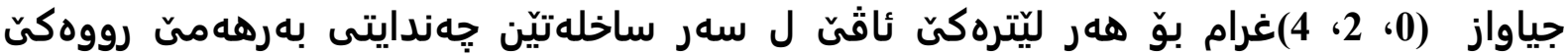

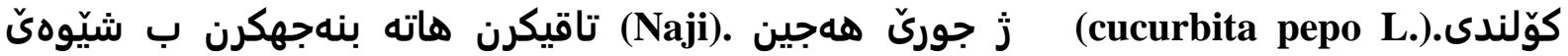

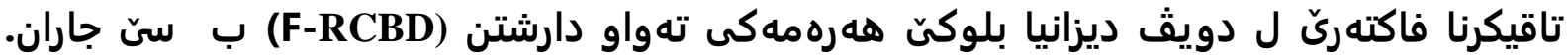

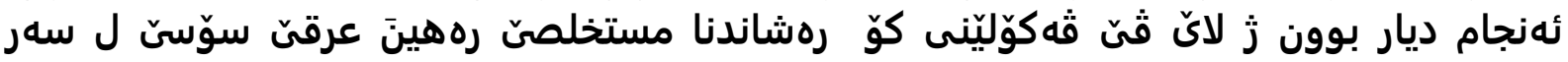

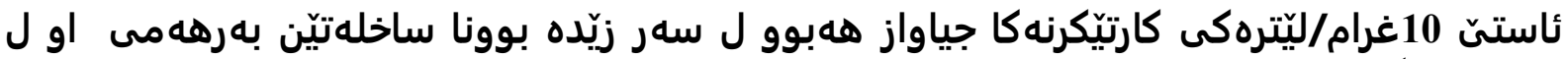

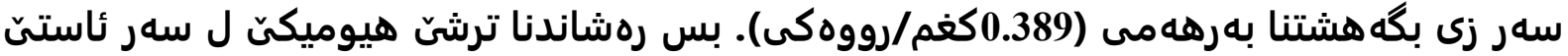

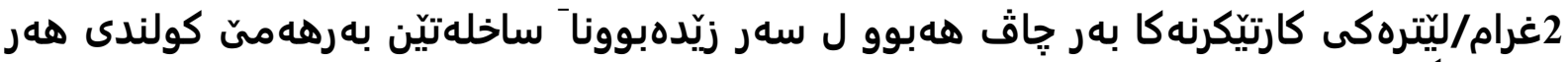

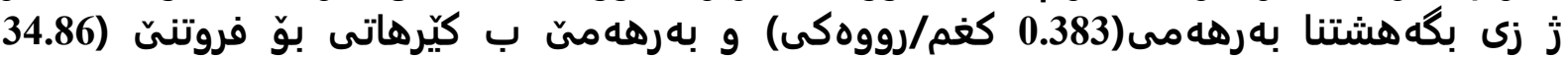

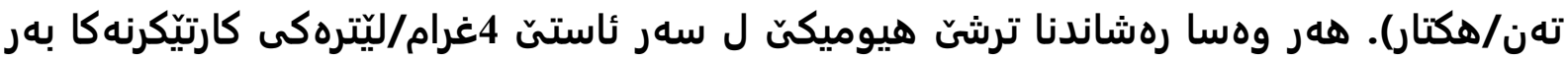

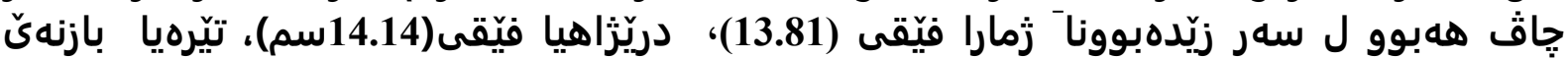

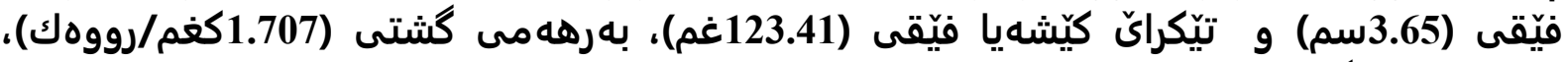

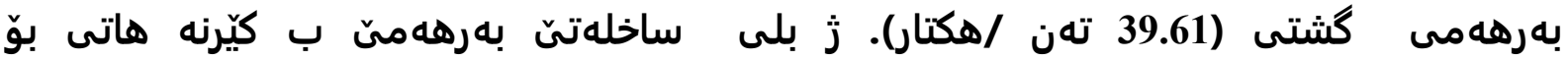

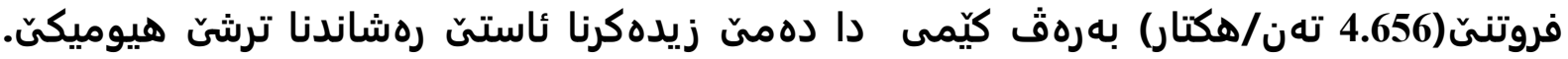

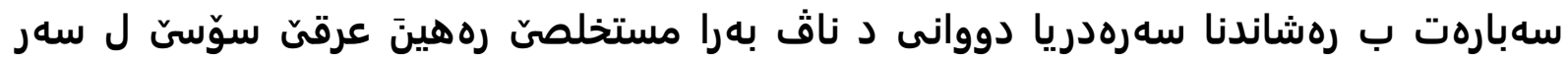

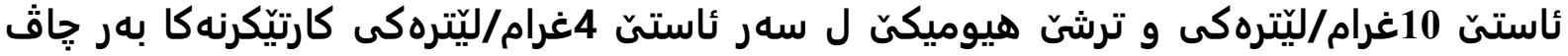

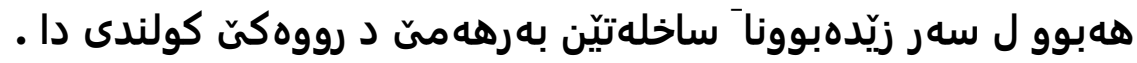


تأثيرمستخلص جذورعرق السوس و حامض الهيوميك على حاصل ثمار قرع الكوسة (Cucurbita pepo L.)

الخلاصـة

أجريت هذه الدراسة في حقول الخضروات / كلية الزراعة في جامعة دهوك /إقليم

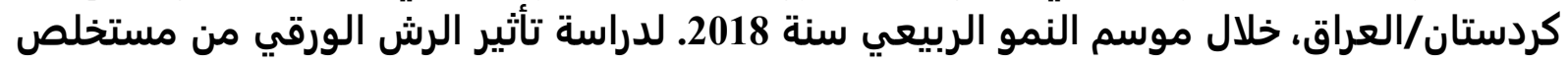

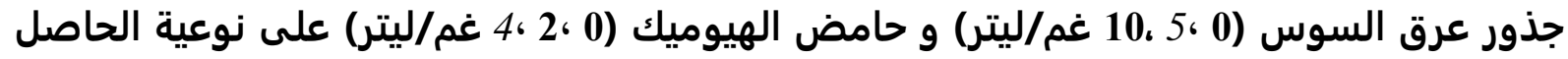

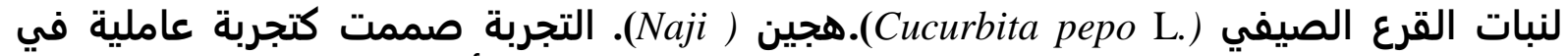

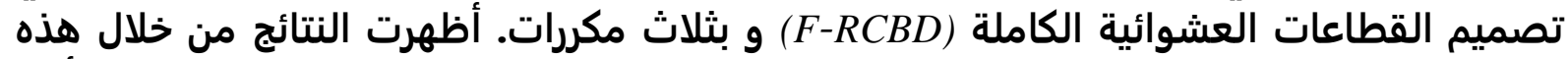

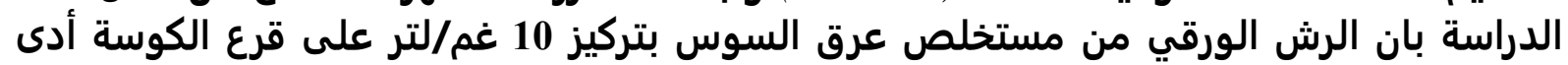

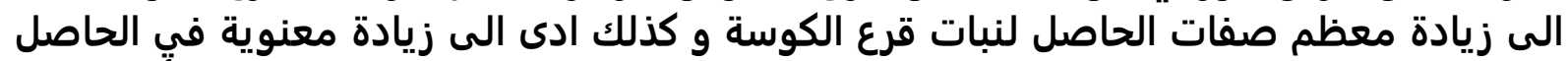

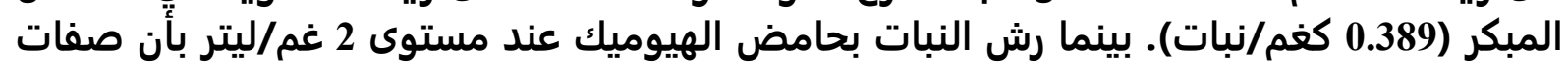

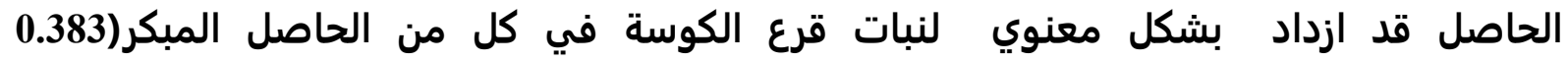

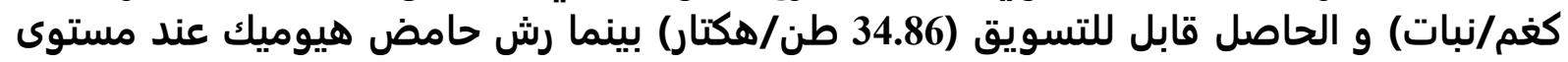

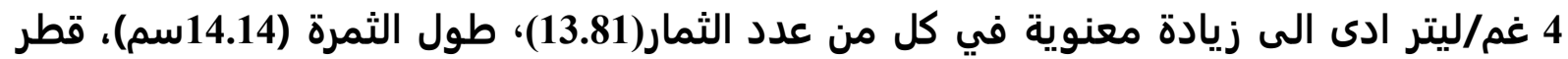

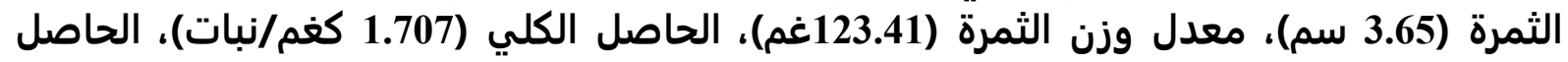

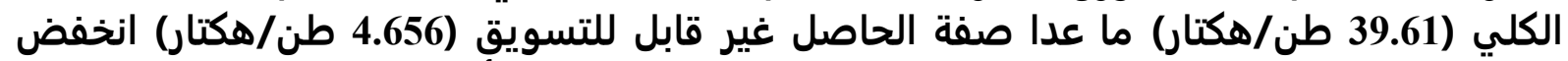

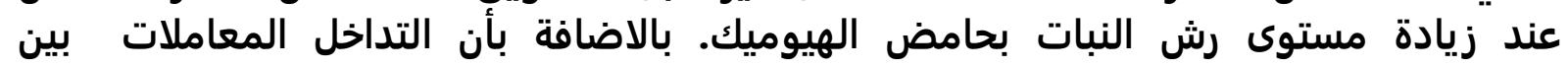

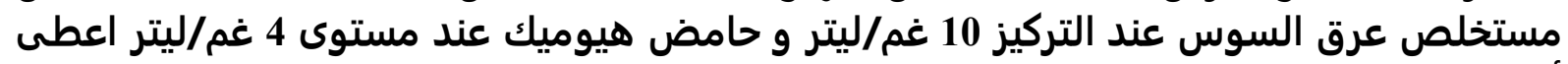
أعلى قيمة بخصوص صفات الحاصل المدروسة لنبات قرع الكوسة. ، 